\title{
As Transformações do Conceito de Ordem Pública
}

\author{
ARNOLD WALD \\ Advogado no Distrito Federal
}

$\mathrm{E}$ NQUANTO as normas imperativas se multiplicam e os autores assinalam a publicação e a socialização do direito, ampliando-se $\alpha$ conceito da ordem pública interna, notamos, ao contrário, uma solidariedade crescente entre os Estados que importa numa restrição do domínio da ordem pública internacional.

São normas de ordem pública interna aquelas que não podem ser revogadas pela vontade das partes, por corresponderem a princípios essenciais de determinado sistema jurídico. Ius publicum privatorum pactis mutari non potest, diziam os romanos confundindo a ordem pública com o direito público. Atualmente, notamos a predominância das normas imperativas ou de ordem pública. No próprio domínio do direito privado, as normas jurídicas geralmente não são mais, como no período do liberalismo individualista, simplesmente subsidiárias, permissivas ou supletivas.

A ordem pública internacional já é um conceito bem diferente e a analogia da terminologia jurídica empregada só leva a confusões de conceitos. São de ordem pública internacional os princípios jurídicos inerentes à estrutura da sociedade e que não podem ser infringidos pela aplicação da lei estrangeira no território nacional. São as normas "que a autoridade soberana de cada estado considera como indispensáveis à boa organização da sociedade que ela rege", (1) "aquelas cujo respeito é necessário ao interêsse geral moral ou material, da sociedade". (2) No Brasil, por exemplo, a indissolubilidade do vínculo matrimonial é matéria de ordem pública internacional que fêz com que, mesmo na vigência da antiga lei de introdução que aplicava a lei nacional das partes, o nosso juiz não concedesse o divórcio a estrangeiros cuja lei pátria o reconhecesse.

À terminologia latina de ordem pública internacional que mereceu severas críticas preferimos aliás o conceito alemão de volbehaltsclausel, cláusula de reserva, de acôrdo com a qual a lei territorial deixa de aplicar a lei estrangeira que seria normalmente competente. E' uma limitação ao alcance das normas de direito internacional privado, dando-se, em certas matérias de interêsse essencial para a sociedade, competência à lex fori, à lei do tribunal.

(1) Despagnet, L'ordre pubiic international Clunet. 1899 , p. 5.

(2) Rolin, Droit international privé, I, p. 309. V. também SAvatier, Cours de droit international privé, 1953, p. 233; BATTIFoL, Traité élémentaire de droit international privé, 1949, p. 374 e ARMINJON, Précis de droit international privé, 1947, 1 vol., página 218 . 
A média que cresce a solidariedade internacional e que as civilizações se aproximam, tornando-se um mundo na palavra de WILKIE, a ordem pública internacional de cada Estado, a cláusula de reserva vê diminuir o seu campo de aplicação.

Muito esclarecedora e sintomática para a história dessa evolução é uma sentença belga de 11 de março de 1954 que tem sido publicada e comentada em diversas revistas especializadas como o Rechtskundig Weekblad, a Pascrisie Belge, a Revue critique de droit international privé, dirigida por BATIFFOL, e a Revue critique de jurisprudence belge.

O acórdão referido do tribunal de Gand, modificando sentença de primeira instância, homologou uma decisão dos tribunais alemães que julgara procedente uma ação de investigação de paternidade baseada na coabitação dos pais durante o período da concepção. Tal ação, fundamentada no artigo 1.717 do Código civil alemão inexistia, pelos mesmos motivos, no direito belga que só admite a investigação de paternidade no caso de posse do estado de filho natural ou nas hipóteses de rapto, sequestro ou estupro. Considerara c juiz belga cie primeira instância que, não sendo o caso previsto pelo seu direito nacional, a sentença estrangeira não poderia ser homologada por não se coadunar com a ordem pública internacional da Bélgica. O tribunal superior, ao estudar a questão, assinalou todavia que se o direito nacional conhecia o instituto da investigação de paternidade, não podia ser considerada contra a ordem pública uma sentença estrangeira que a julgasse procedente mesmo que por fundamentos que não fôssem aqueles admitidos pelo direito nacional para propor a dita ação. "O desenvolvimento harmonioso da comunidade internacional, prossegue o acórdão, exige que a ordem pública internacional não afaste a aplicação do estatuto pessoal senão na medida em que é estritamente necessário". Considera ainda que na Bélgica só são de ordem pública as disposições que consagrar um princípio que o legislador belga reputa como essencial à ordem moral, política ou econômica estabelecida na Bélgica para a seguir entrar numa análise fecunda do direito comparado. Assinala então o julgado que o reconhecimento de paternidade no caso estabelecido pela lei alemã, Vaterschaftsklage, só tem efeitos do ponto de vista dos alimentos e não corresponde ao reconhecimento amplo conhecido pelo direito belga. Ora a ação de alimentos é admitida na hipótese pela lex fori (belga) de modo que nenhuma razão se opõe à homologação da sentença estrangeira.

Duas deduções podemos tirar do acórdão do tribunal de Gand. A primeira se refere à redução do campo da ordem pública internacional, por um princípio de solidariedade internacional crescente. A segunda alude à interpretação material ou real do direito que substitui a interpretação exclusivamente formal. A ação na Alemanha era de investigação de paternidade. O jurista belga, profundo conhecedor do direito comparado que foi relator do processo, Conselheiro ALPHONSE DE VREESE, procurou o têrmo correspondente no direito belga aquela investigação de paternidade e viu que, na realidade, não havia ação de investigação (Vaterschaftsklage) mas simplesmente ação de alimentos (Unterhaltsklage) que o direito alemão confundiu com a investigação por ser a sua causa a filiação presumida. O direito belga que não admitia a investigação de paternidade com base na coabitação co- 
nlıecia todavia a ação de alimentos nela fundamentada. Houve pois uma interpretação sistemática que representa um grande passo e uma importante conquista para o direito comparado. Já aliás MARC ANCEL assinalava que o jurista seguindo a lição de SALEILLES, devia procurar atrás da norma jurídica o espírito da legislação à qual pertencia, pois a diferença ou a semelhança entre as normas jurídicas muito pouco significa por si mesmo. "Replacer la règle de droit dans l'institution dont elle fait partie, replacer ensuite l'institution dans le système juridique dont elle est un des éléments, c'est la précaution que doit prendre tout comparatiste digne de ce nom". (3)

A crítica que o tribunal belga fêz ao juiz de primeira instância quẹ se limitou a constatar a verdade formal sem sondar o que ela escondia é aplicável a alguns dos nossos juízes que em outras matérias. levados pela lei do menor esfôrço, voltam a um formalismo característico dos direitos primitivos. Assim, tivemos o ensejo de ouvir uma sentença que considerava o promitente comprador imitido na posse do imóvel sòmente porque havia cláusula contratual nesse sentido e não obstante o fato provado e reconhecido pelo magistrado de que o promitente vendedor continuava a receber os alugueis do prédio. E' em vão que se pergunta em que pode consistir uma posse quando o possuidor não tem o uso da coisa, pertencente ao locatário, não tem o gòzo e a disponibilidade que ainda estão nas mãos do promitente vendedor. O formalismo é um capítulo do início da história do direito, dizendo PAUL VIOLlet que era um excelente meio de prova perfeitamente adaptado à fraca cultura dos povos bárbaros (4). IHERING fêz em seu Espírito do direito romano excelente análise do formalismo mostrando como, em certa época coube-lhe assegurar a continuidade histórica entre o passado e o presente sôbre a qual repousam a segurança jurídica e as conquistas do progresso. (5)

Voltamos hoje em certas matérias ao formalismo. E' o que acontece especialmentte com os títulos de créditos e com certos documentos que nos oferece o direito marítimo. Já agora o formalismo se justifica por outras e novas razões a saber a facilidade e a rapidez da circulação de certos papéis que representam dinheiro ou bens. Mas a volta aơ formalismo fora dêsses casos especiais seria um regresso condenável.

HENRI DECugIS disse bem: "Le formalisme juridique nous apparaît ainsi comme une des plus fortes garanties de l'ordre social et même du progrès qu'il consolide. Il constitue l'indispensable armature des institutions. Mais il porte en lui-même la cause de leur ruine, quand il s'accroît anormalement au point de leur enlever la flexibilité suffrisante pour leur permettre de s'adapter assez vite aux besoins sans cesse changeants des sociétés humaines progressives". (6)

Vimos pois assim como as interpretações do direito comparado, fugindo ao formalismo, puderam renovar o conceito da ordem pública internacional permitindo assim uma colaboração judiciária mais estreita entre os povos.

(3) MARC ANCEL, La tendance universaliste dans la doctrine comparativiste française au début do XXieme siècle, 1954, TuBINGEN, p. 20-31.

(4) Ap. Decugis, Les étapes du'droit, 1946, 2.a ed., tomo I, p. 291.

(5) IHERING, L'esprit du droit romain, trad. francesa, tomo III, p. 187.

(6) Henri Decugis, Les étapes du droit, 2.a td. p. 312. 